Original Paper http://ajol.info/index.php/ijbcs http://indexmedicus.afro.who.int

\title{
Assessment of benthic molluscs diversity and distribution in urban reservoirs (Ouagadougou, Burkina Faso)
}

\author{
Idrissa OUEDRAOGO*, Adama OUEDA, Djidama SIRIMA, Ilassa OUEDRAOGO, \\ Wendengoudi GUENDA and Gustave B. KABRE
}

\begin{abstract}
Laboratoire de Biologie et Ecologie Animales, UFR-Sciences de la Vie et de la Terre, Université de Ouagadougou 03 BP 7021 Ouagadougou 03, Burkina Faso.

*Corresponding author, E-mail: o.idrissa16@gmail.com; Tel.: 0022670990574
\end{abstract}

\section{ACKNOWLEDGEMENTS}

This study was funded by CIOSPB (Centre d'Information de l'Orientation Scolaire, Professionnelle et des Bourses) and the SUSFISH Project (Sustainable management of fisheries and aquatic resources). We are grateful to them.

\begin{abstract}
The urban reservoirs $n^{\circ} 2$ and $n^{\circ} 3$ of Ouagadougou, located in the middle of the city are subject to multiple anthropogenic pressures which threaten the diversity of benthic macroinvertebrates community group like molluscs. This study was initiated to assess the diversity and distribution of benthic molluscs in these reservoirs. Molluscs samples were collected monthly using an Eckman grab $\left(12\right.$ x $\left.20 \mathrm{~cm}^{2}\right)$ between September 2011 and February 2012 in 24 sampling points defined on each reservoir. In parallel, physicochemical variables and water colon depth were measured. After sampling, molluscs were transported to the laboratory for identification. A total of 328 specimens were collected of which 5 species were identified: three species of Gastropods (Bellamya unicolor, Cleopatra bulimoïdes, Lanistes ovum) and two species of Bivalves (Coelatura aegyptiaca, Mutela rostrata). B. unicolor was the most abundant species with $71 \%$ of the collected molluscs and preferentially occupied the edges of the reservoir. It was followed by $C$. aegyptiaca (27\%) which was abundant in the central axis of the reservoir. Physicochemical variables influence the distribution of species. For all measured physicochemical factors, B. unicolor was more tolerant than C. aegyptiaca on the occupation of available habitat.
\end{abstract}

(C) 2015 International Formulae Group. All rights reserved.

Keywords: Bivalves, Gastropods, available habitat, physicochemical variables, anthropogenic pressures.

\section{INTRODUCTION}

Burkina Faso, a sahelian country located in West Africa, does not enjoy much surface water and this lead to the implementation of a surface water control policy by building many dams throughout the country (Ouéda et al., 2007). The large majority of these reservoirs were created in the Nakanbé River catchment where the population density is high, particularly in and around the city of Ouagadougou. These reservoirs contribute to the local development by providing fisheries (Ouéda et al., 2008), drinking water, water for agriculture (Kpoda 
et al., 2015) and the preservation of biodiversity. But despite their importance, most of these reservoirs do not have sufficient attention and are gradually degrading due to the pressure imposed by human activities. As consequence, this water from some reservoirs (eg. Reservoir 2 and 3 of Ouagadougou) shows higher concentrations of sulphates, nitrates and also heavy metals (mercury, total selenium dissolved and total dissolved arsenic) (Ouédraogo and Aymot, 2013). Aquatic organisms are sensitive to such disturbances that can lead to species disappearance. Zheng et al. (2015) has showed that for $\mathrm{Zn}, \mathrm{Pb}, \mathrm{Cr}, \mathrm{Cd}, \mathrm{Hg}$, and $\mathrm{Cu}$, invertebrates exhibited higher sensitivity than vertebrates. Among these organisms, benthic molluscs are particularly vulnerable because of their limited ability to move and thus to escape pollution. Because of this vulnerability, it is important to assess the diversity of this group in these two reservoirs.

In Burkina Faso, most studies on molluscs have focused only on the distribution of the intermediate hosts of schistosomes (Poda et al., 2004). However, although some are parasites vectors, molluscs play important functions in aquatic ecosystems (El-Wakeil et al., 2013), especially in food chain (Odler et al., 2013), in bioindication (Payet and Obura, 2004; Younger and Reese, 2013) and bioaccumulation (Fang et al., 2001; Usero et al., 2005).

The objective of this study was to highlight the diversity of benthic molluses in these reservoirs and analyse their distribution in relation to some physicochemical variables.

\section{MATERIALS AND METHODS}

\section{Study area}

Our study sites, reservoirs $n^{\circ} 2$ and $n^{\circ} 3$ of Ouagadougou, are located in the central part of the town between longitudes $01^{\circ} 30$ '03.79', $\mathrm{W}$ and $01^{\circ} 33^{\prime} 17.48^{\prime}, \mathrm{W}$ and latitudes $12^{\circ} 23^{\prime} 03,79^{\prime}$ ' $\mathrm{N}$ and $12^{\circ} 23^{\prime} 36,04^{\prime}$ ' $\mathrm{N}$. The reservoir $n^{\circ} 2^{\prime}$ 's surface is 226 ha with a capacity of 2.33 million $\mathrm{m}^{3}$. The dyke's depth is around $288.3 \mathrm{~m}$. The reservoir $\mathrm{n}^{\circ} 3$ 's surface is around 88 ha with a capacity of 3733334 $\mathrm{m}^{3}$. The depth of the dykes is about $288.67 \mathrm{~m}$. Reservoir $n^{\circ} 2$ is situated upstream the reservoir $\mathrm{n}^{\circ} 3$, and water can flow from reservoir $n^{\circ} 2$ to the reservoir $n^{\circ} 3$ throughout 60 rectangular opening $(1.20 \times 0.5 \mathrm{~m})$ situated under the dyke of the reservoir $n^{\circ} 2$ (Gueye, 2004). Created in 1963, these reservoirs are actually impacted by diverse activities, including vegetable gardening (that use prohibited chemicals fertilizers and pesticides); fisheries activities; car washing and regular water withdrawals. Another remarkable impact is the discharge of wastewater and solid wastes directly into the reservoirs from the neighbouring houses.

By means of Garmin GPS 76, 6 transects, each with 4 sampling points, were defined on each reservoir. Then, twenty four sampling points were visited each month during the dry season (from September 2011 to February 2012) in each reservoir.

\section{Environmental variables}

The stations were characterized by using 4 physicochemical variables and depth. Physicochemical variables measured are: temperature, conductivity, $\mathrm{pH}$ and transparency. Apart from the transparency which has been measured with a Secchi disk, the other physicochemical variables were measured with a multiparameter HANNA. The depth of the water column was measured with a ballasted tri -decameter.

\section{Molluscs sampling}

Molluscs was sampled aboard a canoe with an Eckman grab (sampling surface = $0.024 \mathrm{~m}^{2}$ ). In each reservoir, one sample unit was taken from each of the 24 sampling point. After the grab raised, its content was spilled on a sieve (mesh size $0.8 \mathrm{~mm}$ ) and washed to remove the mud. Living specimens and empty shell found were sorted and preserved in alcohol $\left(70^{\circ}\right.$ final concentration). In the laboratory, molluscs specimens were determined using Mandahl-Barth (1978) and Leveque (1980) identifications keys. 


\section{Data analysis}

All the analyses were performed with the R.3.1.1 software (R Development Core Team, 2014) in RStudio (Version 0.98.1049) interface. Statistical tests were performed using the stats package. The Shapiro-Wilk test was first performed to check the normality of physicochemical variables distributions. As all variables are not normaly distributed, we used the Mann Whitney-Wilcoxon test to check variability of physicochemical variables according to reservoirs and also to test the difference between available habitat and those used by species. This test was considered significant for $\mathrm{p}<0.05$.

Rarefaction curve (Magurran, 2004) was used to estimate molluscs species richness in the two reservoirs. It is accompanied by Chao index which gives an estimation of the maximum richness expected in the area. Rarefaction curve was graphed based on the matrix of species using the vegan and BiodiversityR packages (Kindt and Coe, 2005).

To analyse spatial distribution, only the most abundant and species found alive in the reservoir $n^{\circ} 3$ were considered. First, a map of the reservoirs shape and sampling points was created with the adehabitat (Calenge, 2006) and lattice (Sarkar, 2008) packages using geographical coordinates recorded with a GPS (Figure 1). Abundance of species at each sampling point were then projected.

\section{RESULTS}

\section{Physicochemical characteristics of reservoirs}

Figure 2 (A-D) shows the variation of physicochemical variables in the two reservoirs. The median values of transparency, temperature and depth are highest in the reservoir $n^{\circ} 3$ than reservoir $n^{\circ} 2$. The average values of $\mathrm{pH}$ and conductivity are highest in the reservoir $n^{\circ} 2$ than reservoir $n^{\circ} 3$. The Mann Whitney-Wilcoxon test confirmed that these differences in the two reservoirs were all statistically significant $(\mathrm{p}<0.05)$.

\section{Species diversity}

Table 1 shows the taxonomic composition of Molluscs community in the two reservoirs. Five species belonging to five families and two classes (Gastropoda and Bivalves) were identified. Thus, each family is represented by a single species. The class of Gastropoda is composed by Bellamya unicolor Olivier, 1804; Cleopatra bulimoïdes (Olivier, 1804), and Lanistes ovum Peters, 1854. Bivalves are composed by Coelatura aegyptiaca (Cailliaud, 1827) and Mutela rostrata (Rank, 1835). The living specimens found belong to Bellamya unicolor and Coelatura aegyptiaca. Cleopatra bulimoüdes and Mutela rostrata were mentioned on the basis of empty shells. Lanistes ovum was observed in a sample from the reservoir $n^{\circ} 2$ and collected outside the method used for this study.

Rarefaction curve gives no horizontal tangent (Figure 3). This means that the probability to find new species exists if other samplings are conducted. Indeed, the Chao test foresees a total of 8 species in these reservoirs. So we can hypothesize that three more species are susceptible to be found in these reservoirs.

\section{Species abundance}

The relative abundance of benthic molluscs, considering living specimens and empty shell in reservoirs $n^{\circ} 2$ and $n^{\circ} 3$ of Ouagadougou is presented in Figure 4. $B$. unicolor is the most abundant with $71 \%$ of collected specimens. It is followed by Coelatura aegyptiaca (27\%) and Cleopatra bulimoïdes with (2\%). M. rostrata represents less than $1 \%$ of specimens. Figure 5 compares the abundance of empty shells to living molluscs for each species. For all species, empty shells are more abundant than living specimens.

\section{Species distribution}

As C. aegyptiaca and B. unicolor were the two species found alive in this study, they were used for micro-spatial distribution and 
habitat preferendum analysis. The spatial distribution analyses have shown that $C$. aegyptiaca occurs mainly in the middle of the reservoir while $B$. unicolor prefers area near to the bank (Figure 6 (A \& B)).

Figure 7 (A-D) shows for each physicochemical variable, the preferendum for $B$. unicolor and $C$. aegyptiaca. The available $\mathrm{pH}$ varied between 7.3 and 9.61. B. unicolor occupies the same range but $C$. aegyptiaca occupied a narrow niche and is not found for $\mathrm{pH}$ lower than 8.25 and higher than 9. The water temperature ranged between $21.8{ }^{\circ} \mathrm{C}$ and $38.5{ }^{\circ} \mathrm{C}$. With temperature, the two species shows the same behavior like with the pH. B. unicolor, more tolerant to temperature variation, is just absent for temperature higher than $36.7^{\circ} \mathrm{C}$ but $C$. aegyptiaca is sensitive to high temperatures, occupied one more time a narrow niche and disappears beyond $25.2{ }^{\circ} \mathrm{C}$. The conductivity values varied between 221 and $361 \mu \mathrm{S} / \mathrm{cm}$. The two species show opposite patterns according to conductivity. $C$. aegyptiaca prefers high conductivity (preferendum between 311 and $318 \mu \mathrm{S} / \mathrm{cm}$ ) and B. unicolor is seen to avoid higher conductivity (appearing between 223 and 318 $\mu \mathrm{S} / \mathrm{cm})$. In this study, available water depth varied from 50 to $450 \mathrm{~cm}$. However, no living specimen was collected below $1 \mathrm{~m}$ depth and no one beyond $3 \mathrm{~m} \mathrm{C}$. aegyptiaca was found in areas where the water column depth varied between 1 and $1.6 \mathrm{~m}$ and $B$. unicolor was found where the water column depth varies between 1 and $3 \mathrm{~m}$. For the water transparency, it varied from 3 to $56 \mathrm{~cm}$. $C$. aegyptiaca and $B$. unicolor avoid both extreme values. However, C. aegyptiaca is more demanding than $B$. unicolor because its distribution range is lower (21 to $28 \mathrm{~cm}$ ) while those of B. unicolor is between 14 and $47 \mathrm{~cm}$. The Mann Whitney-Wilcoxon test showed that there was no significant difference between the available habitat and the preferendum of B. unicolor. For C. aegyptiaca a significant difference was observed for temperature $(\mathrm{p}=0.0066)$.

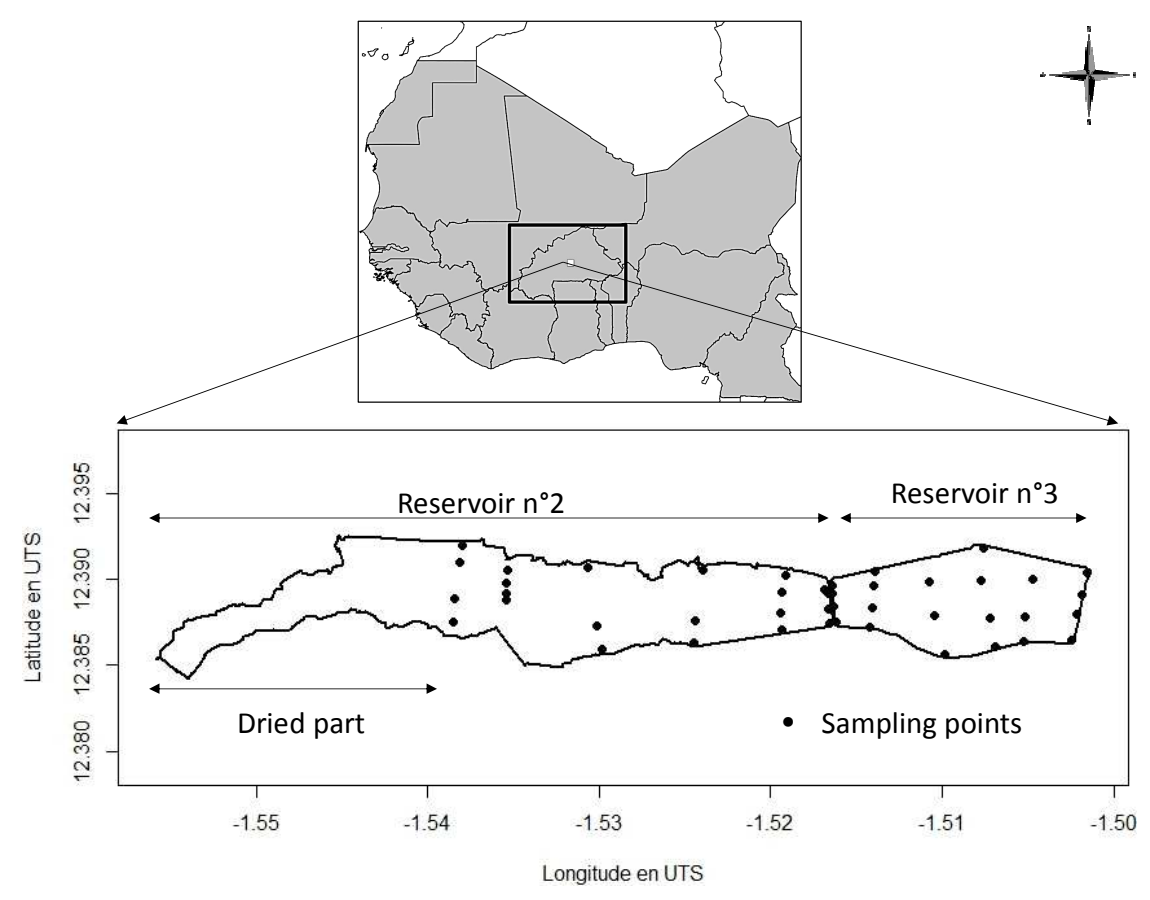

Figure 1: Presentation of study area and sampling design. 

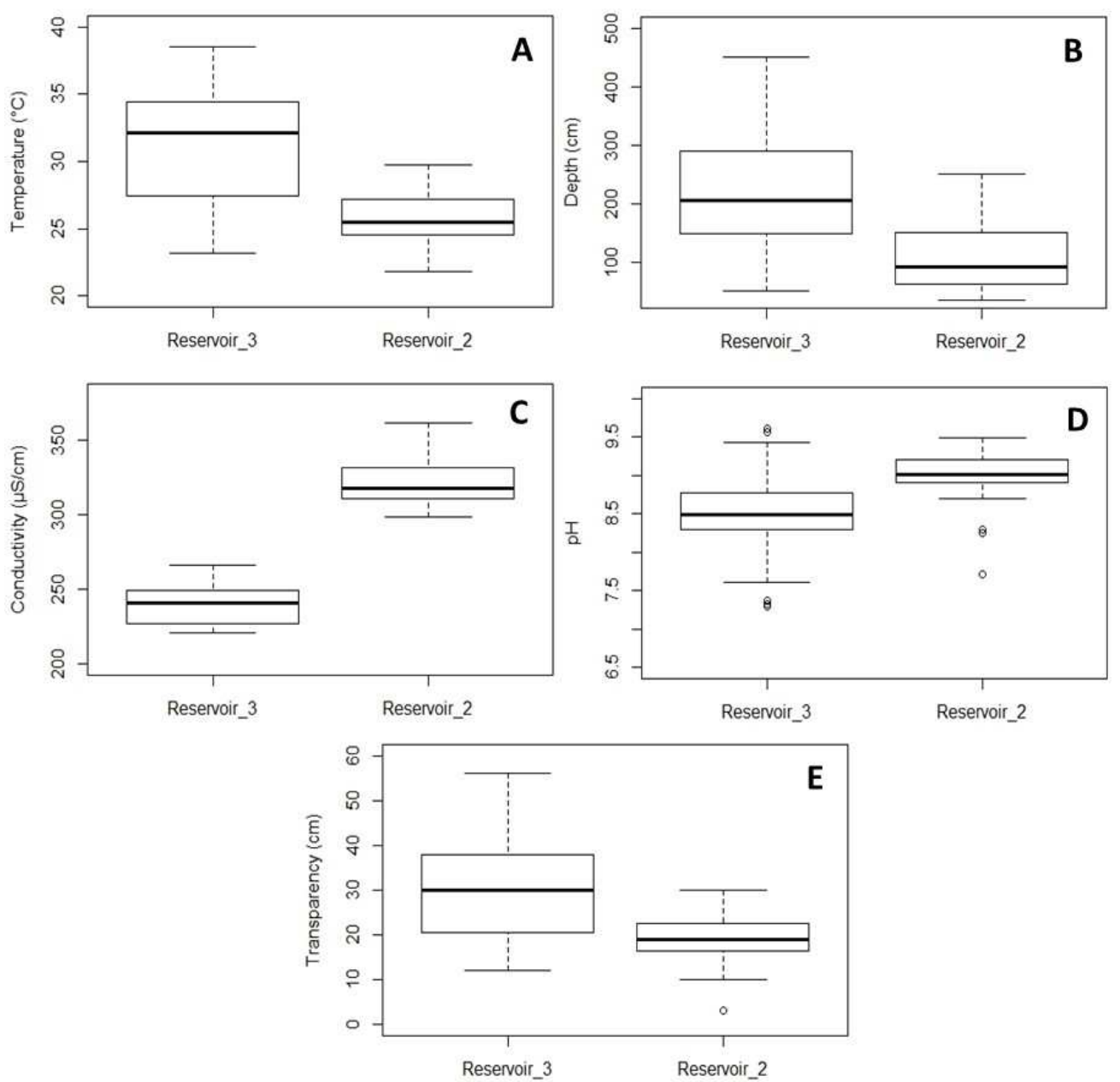

Figure 2: Boxplot showing physicochemical variables distribution in the two reservoirs. $\mathrm{A}=$ temperature $\left({ }^{\circ} \mathrm{C}\right) ; \mathrm{B}=$ Depth $(\mathrm{cm}) ; \mathrm{C}=$ Conductivity $(\mu \mathrm{S} / \mathrm{cm}) ; \mathrm{D}=\mathrm{pH} ; \mathrm{E}=$ Transparency $(\mathrm{cm})$.

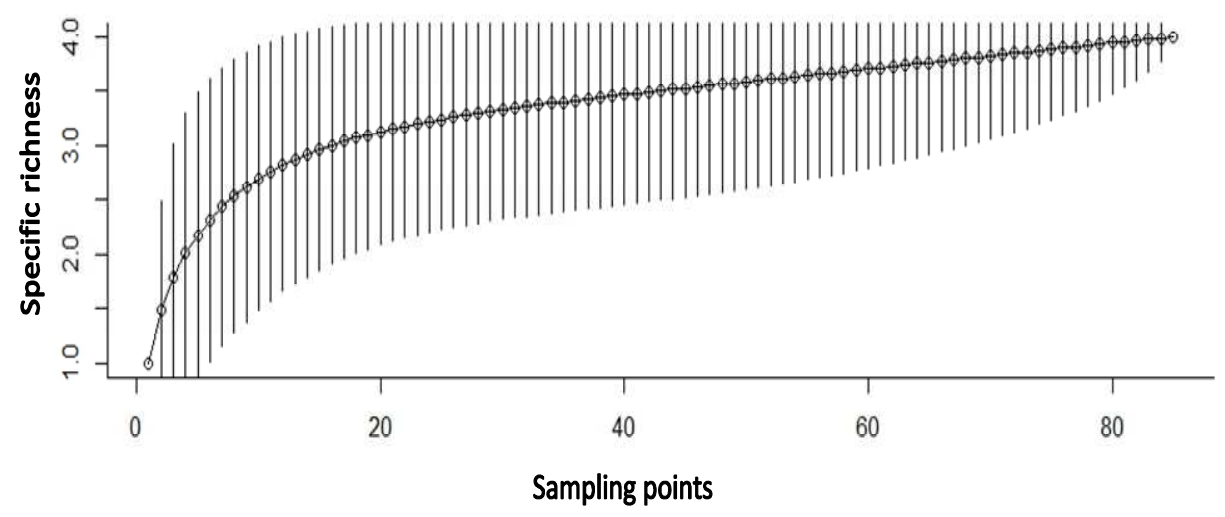

Figure 3: Rarefaction curve in relation to sampling points in the studied reservoirs. 


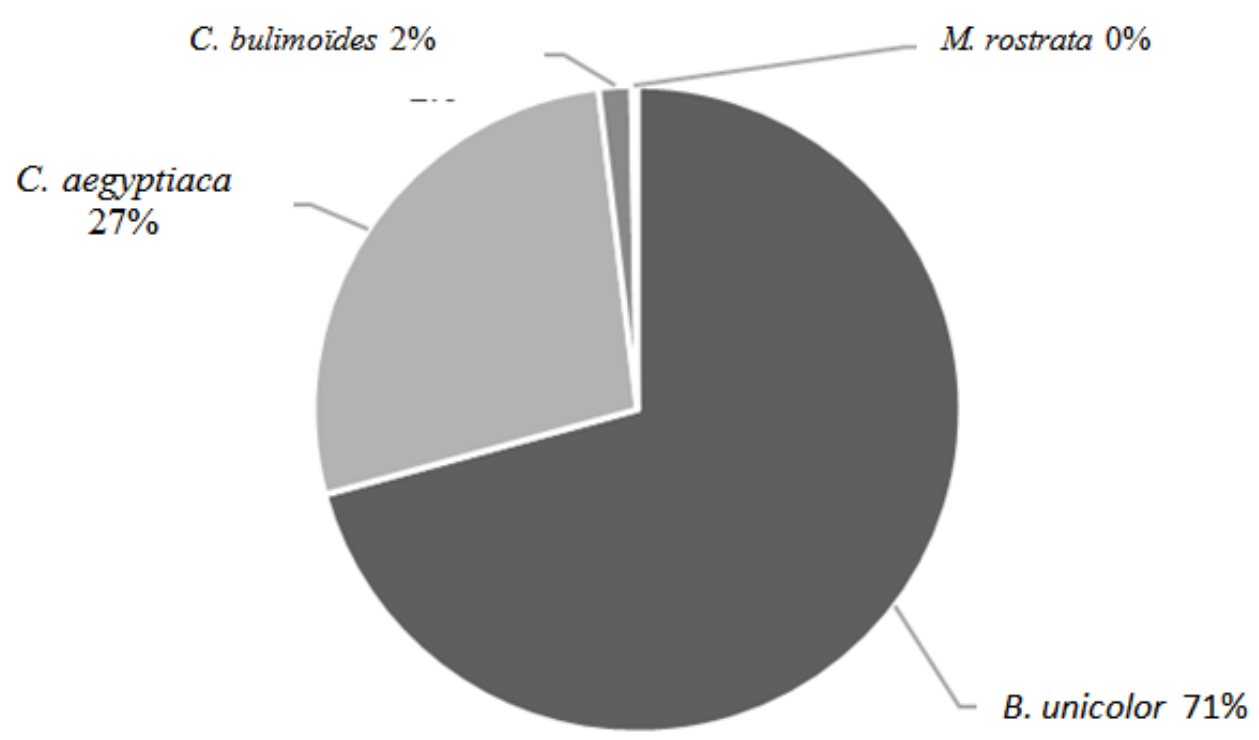

Figure 4: Species proportion in the reservoirs $\left(n^{\circ} 2\right.$ and $\left.n^{\circ} 3\right)$ of Ouagadougou.
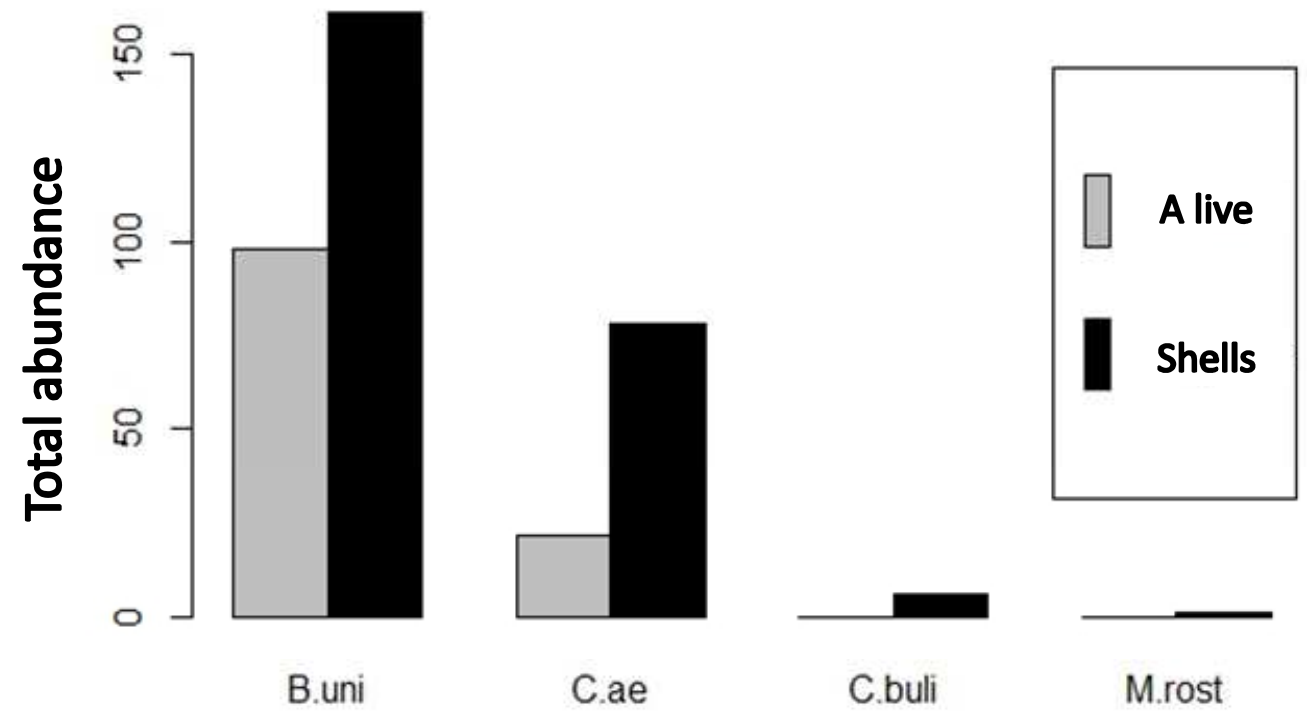

Species

Figure 5: Total abundance of living specimens and empty shells. B.uni: Bellamya unicolor, C.aeg: Coelatura aegyptiaca, Cl.bul: Cleopatra bulimoïdes, M.rost: Mutela rostrata. 

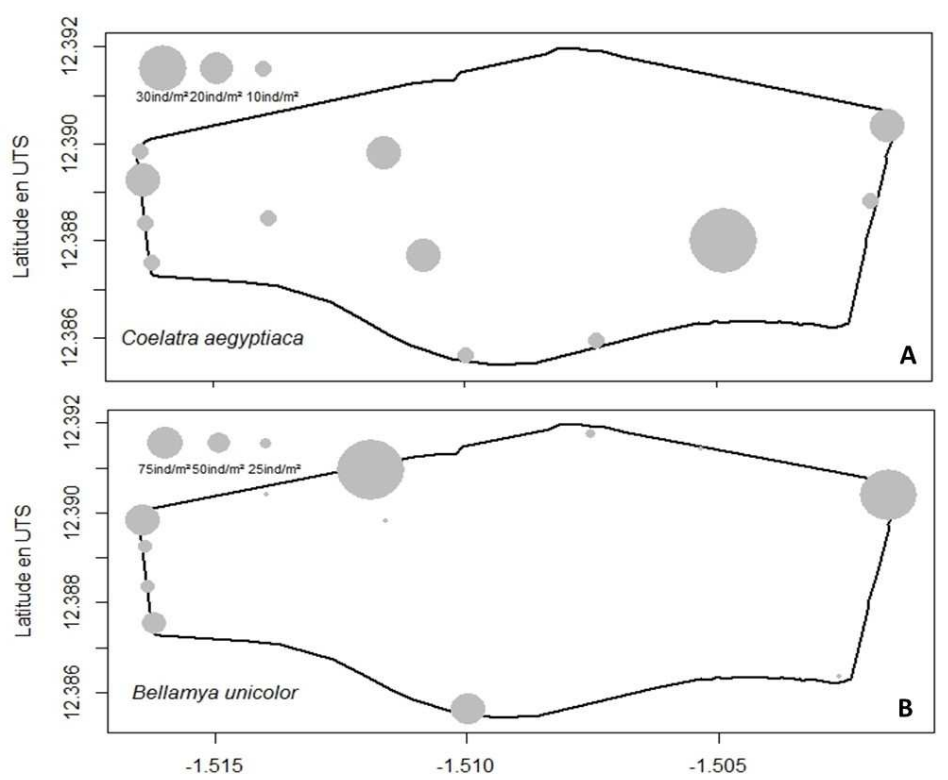

Figure 6: Spatial distribution of C. aegyptiaca and B. unicolor in the reservoir $n^{\circ} 3$ of Ouagadougou. $\mathrm{A}=$ Spatial distribution of $C$. aegyptiaca; $\mathrm{B}=$ Spatial distribution of $B$. unicolor .

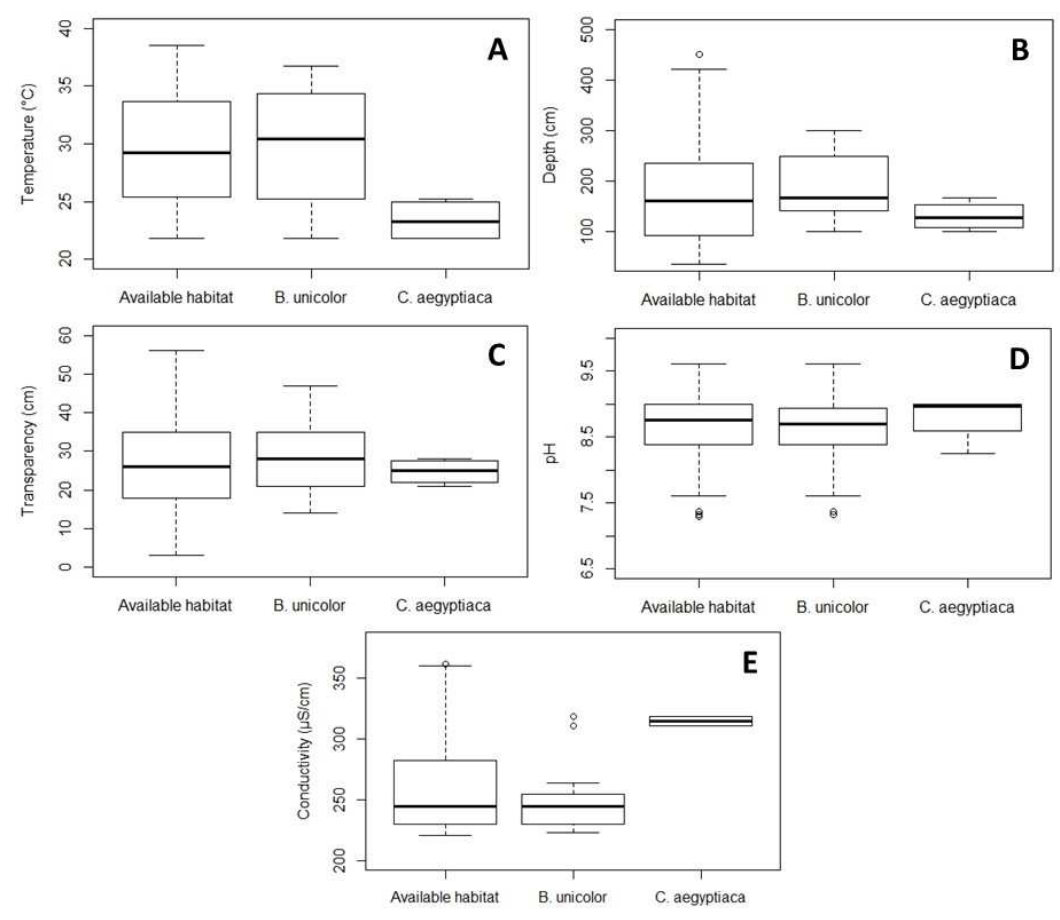

Figure 7: Habitats used by $C$. aegyptiaca and B. unicolor in the reservoir $n^{\circ} 3$ of Ouagadougou. $A=$ Habit use by $B$. unicolor and $C$. aegyptiaca following water temperature; $\mathrm{B}=$ Habit use by $B$. unicolor and $C$. aegyptiaca following water column depth; $\mathrm{C}=$ Habit use by $B$. unicolor and $C$. aegyptiaca following water Transparency; $\mathrm{D}=$ Habit use by $B$. unicolor and C. aegyptiaca following water $\mathrm{pH} ; \mathrm{E}=$ Habit use by $B$. unicolor and C. aegyptiaca following water conductivity. 
Table 1: Taxonomic composition of molluscs in reservoirs $n^{\circ} 2$ and $n^{\circ} 3$ of Ouagadougou.

\begin{tabular}{lcc}
\hline Class & Family & Species \\
\hline Gasteropoda & Viviparidae & Bellamya unicolor Olivier, 1804 \\
& Thiaridae & Cleopatra bulimö̈des (Olivier, 1804) \\
& Ampullaridae & Lanistes ovum Peters, 1854 \\
\hline Bivalvia & Iridinidae & Mutela rostrata (Rang, 1835) \\
& Unionidae & Coelatura aegyptiaca (Cailliaud, 1827) \\
\hline
\end{tabular}

\section{DISCUSSION}

Although interconnected, reservoirs $\mathrm{n}^{\circ} 2$ and $n^{\circ} 3$ of Ouagadougou present differences in their physicochemical characteristics. These differences are probably related to difference in exposition to human activities. There are two things that limit direct access and human activities in the reservoir $n^{\circ} 3$ : first, the banks are completely concrete and second the reservoir $n^{\circ} 3$ is deeper than reservoir $n^{\circ} 2$ (mean: $2.205 \mathrm{~m}$ vs. $1.096 \mathrm{~m}$ ). In contrast to reservoir $n^{\circ} 3$, the reservoir $n^{\circ} 2$ receives wastewater from toilets of neighbouring houses and a part of its bed is used for vegetable gardening where chemical fertilizers and pesticides are usually used (Kpoda et al., 2015). All these practices can explain the high turbidity in the reservoir $n^{\circ} 2$. Wastewaters are characterized by very high concentrations of dissolved elements which increase the electrical conductivity (Abba et al., 2008). The intensive use of chemical fertilizers can make water alkaline resulting to high values of $\mathrm{pH}$ as seen in the reservoir $\mathrm{n}^{\circ} 2$. The lower depth and the connection to the river basin make the reservoir $n^{\circ} 2$ more exposed to human activities and pollution. These impacts and pollution in turn lead to lower transparency and high conductivity of reservoir $\mathrm{n}^{\circ} 2$.

Despite the disturbance affecting the two reservoirs, five species of molluscs were founded. These species, as mentioned by Seddon et al. (2011) for African freshwater molluscs fall into two main groups, the
Bivalves and the Gastropods. While all the five species are new record for Burkina Faso, they were already reported in previous studies on African freshwater molluscs or macroinvertebrates (Sarr et al., 2011; Seddon et al., 2011). Cleopatra bulimö̈des and Mutela rostrata were reported in the sediment of the Agnéby River in Côte d'Ivoire (Diomandé et al., 2009). Bellamya unicolor is widespread in West Africa through the Sahel (Ghamizi et al., 2010). It was recorded in Egypt by Odler et al. (2013). Coelatura aegyptiaca is also widespread in West Africa (Van Damme and Ghamizi, 2010) and was recorded by Odler et al. (2013) in the mudbrick tomb in Abusir (Egypt). Lanistes ovum was recently recorded in south-western Nigeria in Aiba stream by Akindele et al. (2014).

Significant relationship exists between benthic macroinvertebrates and physicochemical variables (Pham et al., 2015). With regard to available habitat (according to physicochemical variables) $B$. unicolor and $C$. aegyptiaca have different preferendums. In general, B. unicolor is more tolerant than $C$. aegyptiaca. For all the studied physicochemical variables, $C$. aegyptiaca shows narrow niche than $B$. unicolor.

A large majority of molluscs species and a large number of specimens develop in alkaline conditions (Martins-Siva and Barros, 2001). The $\mathrm{pH}$ values recorded in this study are slightly alkaline (7.55 to 9.5) and similar 
to those reported by Akindele et al., (2014) in the Aiba stream in Nigeria (6.55-7.55) where they found $C$. aegyptiaca and B. unicolor. In this study, we can go to more details on the preferred $\mathrm{pH}$ range for C. aegyptiaca $(8.25$ and 9).

Any living specimen of molluscs was found beyond $36.7{ }^{\circ} \mathrm{C}$. C. aegyptiaca and $B$. unicolor were previously found in Lake Victoria where the temperature ranged between 24 to $25{ }^{\circ} \mathrm{C}$ (Mwambungu, 2004) in Aiba stream in Nigeria where it ranged from 21.9 to $30.08{ }^{\circ} \mathrm{C}$ Akindele et al., (2014). It is therefore apparent that $36.7{ }^{\circ} \mathrm{C}$ recorded in this study is the bearable limit for these species even if high temperatures are reported to favour their growth in the Ramsagar reservoir (maximum temperature $=31.87{ }^{\circ} \mathrm{C}$ ) (Garg et al., 2009). A future increase of the temperature in these reservoirs due to global warming of the planet could lead to their disappearance (Yasuhara and Donavaro, 2014). This could happen early for $C$. aegyptiaca because Bivalves seem to prefer low temperatures (Saddozai et al., 2013; Sharma et al., 2013).

Compared to Lake Chad where these species were found, conductivity varied between 50 and $550 \mu \mathrm{S} / \mathrm{cm}$ with a maximum density at $400 \mu \mathrm{S} / \mathrm{cm}$ for B. unicolor. It was also present in Lake Victoria where the average conductivity was $123 \mu \mathrm{S} / \mathrm{cm}$ (Mwambungu, 2004). The absence of Cleopatra bulimoïdes does not seem to be related to the conductivity because it was found in the river Agnéby where conductivity ranged between 119.7 and $151.95 \mu \mathrm{S} / \mathrm{cm}$ (Diomandé et al., 2009).

No specimen was found in depth below $1 \mathrm{~m}$. The reservoir $\mathrm{n}^{\circ} 3$ has concrete bank with high slope, then the bottom is found in depth higher than $1 \mathrm{~m}$. In reservoir $n^{\circ} 2$ there is too much activities in the bank, creating too much disturbance that doesn't allow establishment of molluscs community. The average depth of the reservoir $n^{\circ} 3$ of Ouagadougou is similar to the average depth of Lake Chad which varies around 4 to $3 \mathrm{~m}$ (Leveque et al., 1979). This species was found in depths of about $18 \mathrm{~m}$ in Golf Winam near Kisumu (Brown, 1994), but in our study, no specimen was found beyond 3 m. This means that the depth only cannot explain the distribution of this species; it can also be related to the nature of bottom sediments. In this Golf, B. unicolor was abundant in bottom sediment which was mostly fine organic detritus derived from the papyrus swamps (Brown, 1994).

B. unicolor and C. aegyptiaca were found in waters like Lake Victoria where transparency were $1.6 \mathrm{~m}$ (Mwambungu, 2004). Here, we found these species in very turbid water (transparency lower than $60 \mathrm{~cm}$ ). This higher turbidity is not favourable to the development of Gastropods (Brown, 1994). Bivalves by their filtration activities enhance the water clarity by reducing the number of suspended particles (McIvor, 2004).

B. unicolor occurs preferentially near the bank of the reservoir where immerged plants and debris (twigs, sticks, and leaves) are abundant and represented good habitat for them (Leveque, 1979). This habitat preference is the reason why B. unicolor is not found in beyond $3 \mathrm{~m}$. $C$. aegyptiaca is better represented in the central axis of the reservoir. Bivalves seem more related to areas where water velocity is higher (Leveque, 1980) due to their feeding mode by filtering water to retain particles in suspension.

Important quantities of empty shells were found in our samples. Empty shells of $C$. bulimoïdes and $M$. rostrata are indicator of the presence of those species in the reservoir $n^{\circ} 3$. The absence of living specimens of these species can be interpreted in two ways: one, these species had disappeared because pollution of the reservoir has reached an 
unfavorable level to their development, and two, living specimens exist but they are so rare. Molluscs with live specimens have high abundance of empty shells in the two reservoirs. This can be explained by the fact that once molluscs are dead, their shells remain in the sediments take long time to be decomposed. A study of the degradation rate of the shells based on physicochemical conditions of the environment could give light to this phenomenon.

\section{Conclusion}

This study showed that five species of benthic molluscs occur in reservoirs $n^{\circ} 2$ and $\mathrm{n}^{\circ} 3$ of Ouagadougou. Living specimens only belong to two species: $C$. aegyptiaca and $B$. unicolor are also the most abundant. As far as the occupation of available habitat defined with physicochemical variables is concerned, B. unicolor is more tolerant than $C$. aegyptiaca that always shows narrow niche for the measured variables. B. unicolor occurs preferentially near the bank of the reservoir where immerged plants and debris are abundant and represented good habitat for them. C. aegyptiaca is better represented in the central axis of the reservoir.

\section{Competing interests}

The authors declare that they have no competing interests.

\section{Authors' contributions}

IO participated in the conception, study design, field work, sampling systematic, data analyses and manuscript writing. AO also contributed to the conception, study design, data analyses and manuscript editing. DS and IO conducted the field work, sampling and samples procession. WG and GBK designed the study and supervised the work. All authors read and approved the manuscript.

\section{REFERENCES}

Abba E, Nassali H, Benabid M, El Ayadi R, El Ibaoui H. 2008. Contribution à l'étude physicochimique de l'écosystème lacustre Dayet Aoua au Maroc. Rev. Int. Sci. Tech., 4(2): 306-317.

DOI:http://dx.doi.org/10.4314/afsci.v4i2.6 1691

Akindele EO, Liadi AA. 2014. Diversity and response of Benthic Macroinvertebrates to Natural and Induced Environmental Stresses in Aiba Stream, Iwo, Southwestern Nigeria. West. J. Appl. Ecol., 22(1): 101-111.

Brown D. 1994. Freshwater Snails of Africa and their Medical Importance ( $2^{\text {nd }}$ edn). Taylor \& Francis: London.

Calenge C. 2006. The package adehabitat for the R software: a tool for the analysis of space and habitat use by animals. Ecol. Model., 197: 516-519. DOI : 10.1016/j.ecolmodel.2006.03.017.

Diomandé D, Bony YKB, Edia OE, Konan KF, Gourène G. 2009. Diversité des Macroinvertébrés Benthiques de la Rivière Agnéby (Côte d'Ivoire; Afrique de l'Ouest). Eur. J. Sci. Res., 35(3): 368-377.

El-Wakeil KFA, Obuid-Allah AH, Mohamed AH, El-Aziz FEZ, Fatma El-Zahraa AA. 2013. Community structure of molluscans in rivers Nile and its branches in Assiut governorate, Egypt. Egypt. J. Aquat. Res., 39: 193-198.

DOI:10.1016/j.ejar.2013.09.002.

Fang ZQ, Cheungr YH, Wong MH. 2001. Heavy metal concentrations in edible bivalves and gastropods available in major market of the Pearl River Delta. $J$. Environ. Sci., 13(2): 210-217.

Garg RK, Rao RJ, Saksena DN. 2009. Correlation of molluscan diversity with physicochemical characteristics of water of Ramsagar reservoir, India. Int. J. Biodiv. Conserv., 1(1): 202-207. 
Ghamizi M, Jørgensen A, Kristensen TK, Ngereza C, Stensgaard AS, Van Damme D. 2010. Bellamya unicolor. In: IUCN 2012. IUCN Red List of Threatened Species. Version 2012.1. www.iucnredlist.org. Downloaded on 13 September 2012.

Gueye M. 2004. Projet de restructuration urbaine et de protection des berges des barrages $n^{\circ} 2$ et $n^{\circ} 3$ de la ville de Ouagadougou. Mémoire de fin d'étude, Groupe EIER-ETSHER, Ouagadougou, $73 p$.

Kindt R, Coe R. 2005. Tree Diversity Analysis: A Manual and Software for Common Statistical Methods for Ecological and Biodiversity Studies. World Agroforestry Centre (ICRAF): Nairobi.

Kpoda NW, Ouéda A, SOMÉ YSC, Cissé G, Maïga AH, Kabré GB. 2015. Physicochemical and parasitological quality of vegetables irrigation water in Ouagadougou city, Burkina-Faso. African Journal of Microbiology Research, 9: 307-317. DOI : 10.3923/ jfas.2008.240.251

Leveque C, Dejoux, Lauzanne L, 1979. La faune benthique du Lac Tchad: Ecologie, Peuplements et Biomasses. Paris : ORSTOM, 1979, 42 p. Réunion de travail sur la Limnologie Africaine, 1979/12/1623, Nairobi

Leveque C. 1980. Mollusques. In Flore et Faune Aquatiques de l'Afrique SahéloSoudanienne : Tome 1. J.-R. Durand and C. Leveque. ORSTOM : Paris. 1980, 1981/1982; 1283-1305.

Magurran AE. 2004. Measuring Biological Diversity. Blackwell Publishing: Malden, Oxford and Victoria; 256p.

Mandahl-Barth. 1978. A field Guide to African Freshwater Snails. 1: West
African Species. Danish Bilharziasis Laboratory: 30p.

Martins-Siva MJ, Barros M. 2001. Occurrence and Distribution of Fresh-Water Molluscs in the Riacho Fundo Creek Basin, Brasilia. Brazil. Rev. Biol. Trop., 49(3-4): 865-870.

McIvor AL. 2004. Freshwater mussels as biofilters. PhD thesis, University of Cambridge, Cambridge, 70p.

Mwambungu J. 2004. The diversity of benthic molluscs of lake Victoria and lake Burigi. Tanz. J. Sci., 30(1): 21-32. DOI: http://dx.doi.org/10.4314/tjs.v30i1.18384

Odler M, Dulíková V, Juřičková L. 2013. Molluscs from the Stone and Mud-brick Tombs in Abusir ( Egypt) and the Provenance of so-called ' Nile-mud '. iansa IV: 129-140.

Ouéda A, Guenda W, Kabré TA, Zongo F, Kabré BG. 2007. Diversity, abundance and seasonal dynamic of zooplankton community in a South-Saharan reservoir (Burkina Faso). J. Biol. Sci., 7(1): 1-9. DOI: $10.3923 /$ jbs.2007.1.9

Ouéda A, Guenda W, Ouattara A, Gourène G, Hugueny B, Kabre BG. 2008. Seasonal Diet Shift of the Most Important Fish Species in a Sahelo-Soudanian Reservoir (Burkina Faso). J. Fish. Aquat. Sci., 3: 240-251. DOI: 10.3923/jfas.2008.240.251

Ouédraogo O, Aymot M. 2013. Mercury, arsenic and selenium concentrations in water and fish from sub-Saharan semi-arid freshwater reservoirs (Burkina Faso) Sci. Total Env., 444(1): 243-254. DOI: org/10.1016/j.scitotenv. 2012.11.095

Payet R, Obura D. 2004. The Negative Impacts of Human Activities in the Eastern African Region: An International Waters Perspective. AMBIO: A Journal of the Human Environment, 33(1): 24-33. 
Poda JN, Traoré A, Sondo KB, 2004. L'endémie bilharzienne au Burkina Faso. Bull. Soc. Pathol. Exot., 97(1): 47-52.

R Development Core Team, 2014. A Language and Environment for Statistical Computing. R Foundation for Statistical Computing: Vienna, Austria.

Saddozai S, Baloch WA, Achakzai WM, Memon N. 2013. Population dynamics and ecology of freshwater gastropods in Manchar Lake Sindh, Pakistan. J. Anim. \& Plant Sci., 23(4): 1089-1093.

Sarkar D. 2008. Lattice: Multivariate Data Visualization with $\mathrm{R}$ (first eds). DOI: 10.1007/978-0-387-75969-2. 268 p.

Sarr A, Kinzelbach R, Diouf M. 2011. Diversité spécifique et écologie des mollusques continentaux de la basse vallée du Ferlo (Sénégal). MalaCo, 7: 383-390.

Seddon M, Appleton C, Van Damme D, Graf D. 2011. Freshwater molluscs of Africa: diversity, distribution, and conservation. In The Diversity of Life in African Freshwaters: Underwater, Under Threa, Darwall D, Smith K, Alien D, Holland R, Harrison I, Brooks E (Eds), 92-119.

Sharma KK, Bangotra K, Saini M. 2013. Diversity and distribution of mollusca in relation to the physicochemical profile of
Gho-Manhasan stream, Jammu (J \& K). Int. J. Biodiv. Conser., 5(4): 240-249. DOI: $10.5897 / \mathrm{IJBC} 12.127$.

Usero J, Morillo J, Gracia I. 2005. Heavy metal concentrations in mollscs from the Atlantic coast of southner Spain. Chemosphere, 59: 1175-1181. DOI: 10.1016/j.chemosphere.2004.11.089.

Van Damme D, Ghamizi M. 2010. Coelatura aegyptiaca. In IUCN 2012. IUCN Red List of Threatened Species.Version 2012.1. www.iucnredlist.org. Downloaded on 19 September 2012.

Yasuhara M, Danovaro R. 2014. Temperature impacts on deep-sea biodiversity. Biol. Rev., 89(4): 000-000: $\quad$ DOI : 10.1111/brv.12169.

Younger AD, Reese RA. 2013. Comparison of Escherichia coli Levels Between Bivalve Mollusc Species across Harvesting Sites in England and Wales. J. Shellfish Res., 32(2):527-532. DOI: http://dx.doi.org/ 10.2983/035.032.0232.

Zheng X, Zang W, Yan Z, Hong Y, Liu Z, Yi X, Wang X, Liu T, Zhou L. 2015. Species sensitivity analysis of heavy metals to freshwater organisms. Ecotoxicol., 24(4): DOI: 10.1007/s10646-015-1500-2. 